レーザーコンパス

\title{
基礎 研究と応用研究
}

\author{
宅間宏* \\ Hiroshi TAKUMA*
}

最近我が国においても基礎研究の重要性が広 く認識され始めたのは喜ばしいことである。し かし, いろいろな議論の中で,「基礎研究」の 意味するものが人によってかなり異なっている ように感じられる。また基礎研究とはどんなも のか, それが応用研究に対しどのように位置付 けられるのかが必ずしも明確に認識されていな い上うに見えることも多い。そこで，巻頭に当 り，今後ますます重視されるであろう基礎研究 とは何か，またそれが応用研究に対してどのよ うに位置付けられるのかをもう一度考えてみる ことにした。

基礎研究の解釈の一つとして, 特定の目的を 持たずに行なう研究，いわば無目的研究である という考えがある。事実このように考えている 人に会うことが多いが, 基礎研究であっても, 何をどこまで明らかにし，その結果はどのよう な意味を持つかをはっきりと認識していなけれ ば，文部省科学研究費補助金の申請書も書けな いことになる。つまり基礎研究でもそれなりの 目的は明確でなければならないのである。

いっぽうで最近よく見聞きする基礎研究重視 論の多くは，エレクトロニクス，情報科学，バ イオ技術などの重要な応用分野の基礎研究を大 いに振興すべしと言うことである。この場合の 「基礎研究」は, 今後の応用研究に広く役立つ ような研究を意味するのであろう。これらのよ うにすでに応用上の重要性が確立された分野で,
今後の技術的発展に広く役立つような研究とし ては，デバイスやシステムの設計理論の確立と そのために不可欠なデータを, 必要にして十分 なパラメーター領域で求めること，あるいは広 範な目的に柔軟に適用できるような新しいシス テムの開発や，その特性の一般性を特つ解析な どが含まれる。応用上優れた特性を持つ新材料 の開発もこのような基礎研究に含まれる。

このような「基礎研究」は, リスクが少なく, また研究を行なう意義, 応用に対する位置付け ともに明らかである。しばしば「目的基礎研究」 とよばれるこのような研究は, 応用技術の完成 度を高めるために不可欠なものであって，大い に振興されるべきものであることは言うまでも ない。

しかし, 我が国の技術を最高の水準に導きそ れを長期にわたって保つために, 基礎研究とし てそのようなものだけで十分であろうか。基礎 研究のなかには, 自然科学の諸分野を学問とし てょり豊かに, より完成度の高いものにして行 くための研究も含まれているからである。事実, このような基礎学問研究の比重は, ヨーロッパ 先進国では伝統的に非常に高いものであった。 上の問に答えるのに最もよい方法は, 絶好の 例として，レーザー技術が今日までどの様にし て進歩してきたかを思い起こすことである。今 日のレーザー研究者の多くが持つ, レーザーと いう革新的新技術が誕生し, 産業や一般消費者

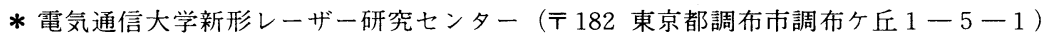

* Institute for Laser Science, University of Electro-Communications (1-5-1, Chofushi, Tokyo 182 ) 
向けの応用技術として発展して行く過程の流れ の中にあった体験は貴重であって，今後の方針 決定に大いに活かさなければもったいない。

SchawlowとTownesによって1958年に発表 された有名な論文ですでに応用上の重要性が指 摘され，大きな期待の中でレーザーは誕生した のであるが，当初のレーザー技術は当然ながら 幼稚で，実用の段階まで発展するには，長期に わたる非常な努力が必要であった。予測された 応用に当初の技術を直ちに結びつけることは難 しく, この段階の応用研究は企業が取上げるの に適当とは言い難い。革新的新技術のこのよう な面の理解不足の故に失望を味わった日本企業 は少なくない。

これの段階の研究を強力に支えたのは主とし てアメリカ政府であった。民間で行なわれた研 究でも, 多くは政府の依託によるものであって, 民間の資金で活発な研究を独自に行ない得たの は, ベル研やIBM基礎研などの限られた特殊な 場所だけであったが, この状況は今日でもあま り変っていない。現在実用上重要となって事業 として成立しているレーザー応用技術の中には, このようにして築かれた基盤の上に発展したも のが多い。

応用研究の重要な部分は, 技術の所産である 新しいデバイスやシステムを工夫し，それらに 現実に実用し得るほどの性能, 信頼性, そして 経済性を与えることである。この場合, 応用研 究の目的を達成するために必要な技術水準が, 現状と大きく掛け離れている場合には，そのギ ヤップを埋めるための基礎研究を行なう必要が あるが、このような研究が実って実用化され, 利益を産むまでの期間は長く，費用もかさむ上 にリスクが大きいので，民間企業の研究対象之 してはなじみ難いのである。我々日本の研究者 は, 軍事研究には関係がない場合が多いので, 基礎的学問研究の役割が極めて重要となる。

技術が革新的であればあるほど，基礎学問の
研究と密接な関係を持つことが予想される。事 実，レーザーは分子分光学研究の所産である。 また新しいレーザーを作るためには、レーザー 物質の分光デー夕が必要である。いっぽう, 分 光学はレーザーの出現によって真っ先にその恩 恵を受けることとなった。例えば，レーザーの 高輝度の利用によって, 分光測定の感度が著し く向上し，ただ 1 個の原子やイオンのスペクト ルをよいS/Nで測定することさえできること になった。また原子や分子とレーザーのコヒー レントあるいは非線形相互作用を巧に利用する ことによって, 可視領域のスペクトル線を先鋭 化する高分解能非線形分光法は, 従来の分光学 的手法の限界をはるかに越える高分解能を可能 としたことも画期的と言えよう。

このようにして, 産業応用にはまだ未熟であ ったレーザー技術の初期段階では, 先ず基礎科 学の新領域を開拓するためにレーザーが巧に利 用された。研究上のニーズに刺激されてベンチ ヤービジネスが生れ，レーザーの技術的発展を 刺激し，産業的基盤を形成した。そこからウラ ン濃縮のような産業応用が発展してきたのであ る。基礎科学研究では装置を扱うのは熟練した 研究者であり，信頼性や使い易さよりも性能が 重視される。いっぽうで性能に対する要求は最 も厳しく, 競争も激しい。これらの要素によっ て, 基礎研究はレーザー技術を産み出すだけで なく, 応用可能な技術へと発展させるための大 きな推進力ともなったのである。

基礎的な学問研究と応用技術のこのような関 わり合いは，従来あまりはっきりとは認識され ていなかったように思われる。政府予算による 研究, 特に大学における研究として, このよう な意味での基礎研究を積極的に取上げることは， 将来の我が国の技術と産業の発展のため極めて 有効なものであることを多くの産・官・学の諸 氏にご理解いただければ幸いである。 